\title{
The Risk Level of Viet Nam Listed Medical and Human Resource Company Groups After the Global Crisis 2009-2011
}

\author{
Dinh Tran Ngoc Huy \\ International University of Japan, Japan \\ *Corresponding author: Dinh Tran Ngoc Huy, MBA, PhD candidate, Banking University, HCMC-GSIM, International University of Japan, Japan \\ Submission: September 08, 2017; Published: November 15, 2017
}

\begin{abstract}
This paperwork gives some quantitative results based on evaluating the market risk of the listed firms in the Viet nam medical and human resource industry, esp. after the financial crisis 2009-2011. First, by using quantitative and analytical methods to estimate asset and equity beta of total 45 listed companies in Viet Nam medical and human resource industry with a proper traditional model, we found out that the beta values, in general, for many institutions are acceptable. Second, we recognized that the risk level, measured by equity and asset beta mean, decreases when using leverage (asset beta mean value of 0,316 decreasing from equity beta mean of 0,528). Third, by changing leverage in 3 scenarios, we recognized the dispersion of risk level, measured by equity beta var of 0,711 , in the medicine industry is the highest (but acceptable), compared to the rest 2 industries. Finally, this paper provides some outcomes that could provide companies and government more evidence in establishing their policies in governance.
\end{abstract}

Keywords: Equity beta; Financial structure; Financial crisis; Risk; External financing; Medical industry

\section{Introduction}

In many recent years, Viet Nam medical and human resource industry (called medical and human resource industry in this paperwork) is considered as one of active economic sectors in local financial markets, which has some positive effects for the economy. The public utilities industry is selected because until now there is no research published with the same scope. This paper is organized as follow. The research issues and literature review will be covered in next sessions 2 and 3, for a short summary. Then, methodology and conceptual theories are introduced in session 4 and 5. Session 6 describes the data in empirical analysis. Session 7 presents empirical results and findings. Next, session 8 covers the analytical results. Then, session 9 presents empirical results and session 10 presents analysis of risk. Lastly, session 11 shows discussion and session 12 will conclude with some policy suggestions. This paper also supports readers with references, exhibits and relevant web sources.

\section{Research issues}

We mention some issues on the estimating of impacts of external financing on beta for listed medical and human resource industry companies in Viet Nam stock exchange as following:

Issue 1: Whether the risk level of medical and human resource industry firms after the crisis 2009-2011 increase or decrease so much.
Issue 2: Whether the disperse distribution of beta values become large after the crisis 2009-2011 in the medical and human resource industry.

\section{Literature review}

Eugene FF \& French KR [1] also indicated in the three factor model that "value" and "size" are significant components which can affect stock returns. They also mentioned that a stock's return not only depends on a market beta but also on market capitalization beta. The market beta is used in the three factor model, developed by Fama and French, which is the successor to the CAPM model by Sharpe, Treynor and Lintner. Next, Peter and Liuren (2007) mentions equity volatility increases proportionally with the level of financial leverage the variation of which is dictated by managerial decisions on a company's capital structure based on economic conditions. And for a company with a fixed amount of debt, its financial leverage increases when the market price of its stock declines. Then, Chava and Purnanandam (2009) mentioned leverage is positively correlated with financial distress and distress intensity is negatively related to future returns. Reinhart and Rogoff (2009) pointed the history of finance is full of boom-and-bust cycles, bank failures, and systemic bank and currency crises. Mishra (2009) said in India the global economic slowdown the US real estate decline the credit crisis are all creating worry in capital markets. And the study of volatility is imperative in the emerging market such 
as India. As Peirero LE [2] pointed, the task of estimating cost of equity in emerging markets is more difficult because of problems such as collecting data in short periods. Then, Velez-Pareja (2011) referred to the lack of inadequate information on the stock market in emerging countries may undermine beta and relevant formulas. Marcin, Mariusz, Marek, and Karol (2012) mentioned that the reliability and fitness of calculated betas are relevant to the valuation and investment of investors in emerging markets. Umar [3] found that firms which maintain good governance structures have leverage ratios that are higher (forty-seven percent) than those of firms with poor governance mechanisms per unit of profit. Chen [4] supported regulators' suspicions that over-reliance on shortterm funding and insufficient collateral compounded the effects of dangerously high leverage and resulted in undercapitalization and excessive risk exposure for Lehman Brothers. The model reinforces the importance of the relationship between capital structure and risk management. Then, Alcock [5] found evidence that leverage cannot be viewed as a long-term strategy to enhance performance, but in the short term, managers do seem to add significantly to fund excess returns by effectively timing leverage choices to the expected future market environment. And Gunaratha [6] revealed that in different industries in Sri Lanka, the degree of financial leverage has a significant positive correlation with financial risk. Finally, financial leverage can be considered as one among many factors that affect business risk of consumer good firms.

\section{Conceptual Theories}

\section{Determinants of equity and asset beta}

A sound and effective financial system has positive effect on the development and growth of the economy [7]. Financial institutions not only help businesses to reduce agency problems but also enable them to enhance liquidity capacity and long-term capital. And financial innovation also reduces the cost of diversification. So, finance and growth has interrelated. In financial markets, systematic risk relates to the overall risk of the whole market, is affected by some factors such as: interest rate fluctuations or economic crisis, cannot be avoided by diversification, and is measured by a financial metric, beta which is also called systemic risk.

Several factors affecting beta include, but not limit to, the volatility of expected return of a single stock, or the volatility of the expected return of the entire stock market index. Generally, beta values may vary from 0 to 2 with a few values $<0$ in some specific cases and most values fall within a range from 0 to 1 . In special cases, beta values can be higher than (>) 2, which means that the stock returns fall or rise doubling the values of the market returns. They are called higher-beta stocks and become riskier with the potential for higher return. And firms with beta $>1$ will have the movement of stock price higher than the market benchmark [8]. Unlevered beta measures how much systematic risk a firm has, without debt, compared to the benchmark in the stock market. Equity beta covers systematic risk of a firm's equity while asset beta mentions that risk which a firm's asset has.

\section{Methodology}

For calculating systemic risk results and leverage impacts, in this study, we use the live data during the crisis period 2009-2011 [9] from the stock exchange market in Viet Nam (HOSE and HNX and UPCOM). In this research, analytical research method is used, philosophical method is used and specially, historical analysis method is used. Analytical data is from the situation of listed medical and human resource industry firms in VN stock exchange and current tax rate is $25 \%$. Generally speaking, quantitative method is mainly used in this study with a note that risk measure asset beta is mainly derive from equity beta and financial leverage. Finally, we use the results to suggest policy for both these enterprises, relevant organizations and government [10].

\section{General Data Analysis}

Through the analysis of 14 firms in categories of industries: medical and human resource companies groups, the mean of equity beta is about 0,528 and that of asset beta is about 0,316 (lower) (Table 1). This shows us the effectiveness of using financial leverage to reduce the overall riskiness of the 3 industries. And these data are acceptable values during the crisis. While there is bigger difference in beta max values $(1,01)$, the difference in beta mean values is smaller (around 0,21 ). In addition to, there is a difference in the sample variance of asset and equity beta values. The sample variance of asset beta is lower $(0,14)$, while that of equity beta is a little bit higher $(0,56)$, with a gap of 0,42 . This shows us, once again, that the effectiveness of using financial leverage has decreased the systemic risk for the whole industry. Beside, max equity beta value is up to 2,091 that are a little bit high, compared to max asset beta value is just 1,075 that is acceptable. The below Table 2 shows us that a few companies still has larger risk exposure than most of the others [11].

Table 1: Estimating beta results for Three Viet Nam Listed Medical and Human resource Companies Groups (as of Dec 2012) (source: Viet Nam stock exchange data).

\begin{tabular}{|c|c|c|c|}
\hline $\begin{array}{c}\text { Statistic } \\
\text { Results }\end{array}$ & Equity Beta & $\begin{array}{c}\text { Asset Beta (Assume } \\
\text { Debt Beta = 0) }\end{array}$ & Difference \\
\hline MAX & 2,091 & 1,075 & 1,015 \\
\hline MIN & $-0,946$ & $-0,163$ & $-0,783$ \\
\hline MEAN & 0,528 & 0,316 & 0,212 \\
\hline VAR & 0,565 & 0,145 & 0,420 \\
\hline \multicolumn{4}{|c|}{ Note: Sample size : 14 firms } \\
\hline
\end{tabular}

Table 2: The number of companies in research sample with different beta values and financial leverage.

\begin{tabular}{|c|c|c|c|}
\hline Equity Beta & No. of Firms & $\begin{array}{c}\text { Financial } \\
\text { Leverage } \\
\text { (Average) }\end{array}$ & Ratio \\
\hline$<0$ & 3 & $76,1 \%$ & $21,4 \%$ \\
\hline $0<$ beta $<1$ & 8 & $55,1 \%$ & $57,1 \%$ \\
\hline Beta $>1$ & 3 & $36,4 \%$ & $21,4 \%$ \\
\hline Total & 14 & $55,6 \%$ & $100,0 \%$ \\
\hline
\end{tabular}




\begin{tabular}{|c|c|c|c|}
\hline Asset Beta & No. of Firms & $\begin{array}{c}\text { Financial } \\
\text { Leverage } \\
\text { (Average) }\end{array}$ & Ratio \\
\hline$<0$ & 3 & $76,1 \%$ & $21,4 \%$ \\
\hline $0<$ beta $<1$ & 10 & $54,0 \%$ & $71,4 \%$ \\
\hline Beta $>1$ & 1 & $9,7 \%$ & $7,1 \%$ \\
\hline Total & 14 & $55,6 \%$ & $100,0 \%$ \\
\hline
\end{tabular}

And values of equity beta varies in a range from 2,091 (max) to $-0,946(\mathrm{~min})$ and that of asset beta varies in a range from 1,075 ( $\max )$ to $-0,163(\mathrm{~min})$. There are 3 listed companies with beta lower than $(<) 0$ showing the stock return moving opposite to the market index (Table 2). Therefore, if beta of debt is assumed to be zero the company's financial leverage contributes to a decrease in the market risk level. Last but not least, different from some other industries, there is a bigger difference between equity and asset beta variance values which is just 0,42 , compared to the relatively higher gap between average equity and average asset beta values, which is about 0,21 . So, there is bigger effect in reducing risk dispersion from financial leverage on the gap between company's beta variance values. Generally speaking, there is $57 \%$ of listed firms in 3 industries with acceptable beta values lower than $(<) 1$ and higher than (>) 0 whereas there is $21 \%$ of these listed firms having beta higher than (>) 1 and having more market risks. This number is somewhat high. And $57 \%$ of firms with acceptable beta values use more financial leverage than the $21 \%$ (55\% compared to $36 \%$ ) [12].

\section{Empirical Research Findings and Discussion}

\section{A- Medicine listed companies group}

During the crisis 2007-2011, the market for these companies still exists, but has certain difficulties. The rising inflation and rising lending interest rates and higher opportunity costs makes input materials costs increasing. So, the market for these firms has been affected because selling prices increase [13]. The Table 3 below shows us the research of 8 listed firms in this category during the above period. In general, the mean of equity beta and asset beta are 0,665 and 0,406, accordingly. These values are good numbers in term of indicating a low and acceptable un-diversifiable risk.

Table 3: Estimating beta results for Viet Nam Listed Medicine Companies (as of Dec 2012) (source: Viet Nam stock exchange data).

\begin{tabular}{|c|c|c|c|c|c|}
\hline Order No. & Company Stock Code & Equity Beta & Asset Beta (Assume Debt Beta $=$ 0) & $\begin{array}{c}\text { Financial Leverage } \\
\text { (F.S Reports) }\end{array}$ \\
\hline 1 & AMV & 1,191 & 1,075 & $9,7 \%$ \\
\hline 2 & APC & 0,419 & 0,383 & DLV as comparable & $8,6 \%$ \\
\hline 3 & DBM & 2,091 & 0,765 & PGT as comparable & $63,4 \%$ \\
\hline 4 & DBT & 0,661 & 0,192 & PGT as comparable & $70,9 \%$ \\
\hline 5 & DCL & 0,700 & 0,312 & PGT as comparable & $55,4 \%$ \\
\hline 6 & DDN & $-0,946$ & $-0,163$ & & $82,8 \%$ \\
\hline 7 & DHG & 0,592 & 0,432 & & $27,2 \%$ \\
\hline 8 & DHT & 0,610 & 0,251 & Average & $58,8 \%$ \\
\hline
\end{tabular}

Besides, the variance of equity beta of the sample group equals to 0,71 which is higher than the variance of the entire sample equity beta of 0,56 whereas the variance of asset beta is measured at 0,14 which is lower than entire sample asset beta of 0,145 . This is one characteristic of this industry. We might note that equity beta value of 8 firms in this material category $(0,66)$ is the highest among those of firms in 3 groups. This might be considered as another characteristic of these industries. Among three industries, the systemic risk of medicine group companies is a bit higher than those of the rest groups (Table 4).

Table 4: Statistical results for Vietnam listed Medicine companies.

\begin{tabular}{|c|c|c|c|}
\hline Statistic Results & Equity Beta & Asset Beta (Assume Debt Beta = 0) & Difference \\
\hline MAX & 2,091 & 1,075 & 10,153 \\
\hline MIN & $-0,946$ & $-0,163$ & $-0,7831$ \\
\hline MEAN & 0,665 & 0,406 & 0,2589 \\
\hline VAR & 0,7106 & 0,1400 & 0,5705 \\
\hline \multicolumn{2}{|c|}{ Note: Sample size : 8 } \\
\hline
\end{tabular}

Table 5: Statistical results for Vietnam listed Medical equipment companies.

\begin{tabular}{|c|c|c|c|}
\hline Statistic Results & Equity Beta & Asset Beta (Assume Debt Beta = 0) & Difference \\
\hline MAX & 0,168 & 0,056 & 0,1118 \\
\hline MIN & 0,025 & 0,003 & 0,0220 \\
\hline MEAN & 0,096 & 0,029 & 0,0669 \\
\hline VAR & 0,0102 & 0,0014 & 0,0088 \\
\hline
\end{tabular}




\section{B- Medical equipment listed companies group}

In an emerging market such as Viet Nam, the market for medical equipment firms is definitely established and potential because of the public need for such necessary products and though it may be affected by impacts from the financial crisis. And this is the industry with the smallest sample size in this study [14-20]. The Table 5 below shows us the equity and asset beta mean of 2 listed software companies, with values of 0,096 and 0,029 accordingly. This result, which means the risk is low and acceptable as the equity beta value is the smallest in all 3 groups. This partly, maintains the investor confidence of business operation of the whole industry and partly, indicates the good effect from using financial leverage. Besides, the variance of beta values among these 2 firms is normal, from 0,01 to 0,001 for equity and asset beta, accordingly. Please refer to Table 5 for more information.

\section{C- Human resource listed companies group}

Among 4 groups, this is the group with the relatively small number of listed firms (sample size $=4$ ) and with the moderate equity beta var value of about 0,607 . Then, the asset beta mean of about 0,278 is a little higher than that of the medical equipment industry. Different from firms in the other industries, 4 listed HR firms has moderate equity beta mean value but has the 2 nd highest equity beta var value, estimated at 0,469 and 0,607, which implies there is a less concentration in market risks among firms in this industry. The equity and asset beta values are distributed in a longer range, from 1,502 to $-0,199$, and from 0,958 to $-0,058$, compared to those of medical equipment group, esp., asset beta value is quite acceptable, indicating the effectiveness of using financial leverage. Please refer to Table 6 for more information.

Table 6: Statistical results for Vietnam listed Human resource companies.

\begin{tabular}{|c|c|c|c|}
\hline Statistic Results & Equity Beta & Asset Beta (Assume Debt Beta $=\mathbf{0})$ & Difference \\
\hline MAX & 1,502 & 0,958 & 0,5436 \\
\hline MIN & $-0,199$ & $-0,058$ & $-0,1412$ \\
\hline MEAN & 0,469 & 0,278 & 0,1914 \\
\hline VAR & 0,6075 & 0,2214 & 0,3861 \\
\hline \multicolumn{2}{|c|}{ Note: Sample size : 4 } \\
\hline
\end{tabular}

Comparison among 3 groups of medical and human resource companies

In the below chart, we can see among the 3 groups, equity beta value of the medical equipment group is the lowest $(0,096)$ and asset beta value of this group is the lowest $(0,029)$. Assuming debt beta is 0 , financial leverage has helped many listed firms in these industries lower the un-diversifiable risk. Additionally, we see the asset beta mean values of three groups have certain difference and acceptable. Next, we can recognize from the chart that, the risk in the medical equipment industry lower than that in the rest industries. Last but not least, from the calculated results, variance of asset beta

Table 7: Interest rates, Inflation, GDP growth and macroeconomics factors (Source: Viet Nam commercial banks and economic statistical bureau).

\begin{tabular}{|c|c|c|c|c|c|c|}
\hline Year & Basic rates & Lending rates & Deposit rates & Inflation & GDP & USD/VND rate \\
\hline 2012 & $\mathrm{n} / \mathrm{a}$ & $12 \%-15 \%$ & $9 \%$ & $6,81 \%$ & $5,03 \%$ & 20.828 \\
\hline 2011 & $9 \%$ & $18 \%-22 \%$ & $13 \%-14 \%$ & $18 \%$ & $5,89 \%$ & 20.67 \\
\hline 2010 & $8 \%-9 \%$ & $19 \%-20 \%$ & $13 \%-14 \%$ & $\begin{array}{l}11,75 \% \text { (Estimated } \\
\text { at Dec 2010) }\end{array}$ & $6,5 \%$ (expected) & 19.495 \\
\hline 2009 & $7 \%$ & $9 \%-12 \%$ & $9 \%-10 \%$ & $6,88 \%$ & $5,2 \%$ & 17 \\
\hline 2008 & $8,75 \%-14 \%$ & $19 \%-21 \%$ & $15 \%-16,5 \%$ & $22 \%$ & $6,23 \%$ & 17.7 \\
\hline 2007 & $8,25 \%$ & $12 \%-15 \%$ & $9 \%-11 \%$ & $12,63 \%$ & $8,44 \%$ & 16.132 \\
\hline 2006 & $8,25 \%$ & & & $6,6 \%$ & $8,17 \%$ & \\
\hline 2005 & $7,8 \%$ & & & $8,4 \%$ & & \\
\hline Note & \multicolumn{6}{|c|}{ Approximately (2007: required reserves ratio at SBV is changed from 5\% to $10 \%$ ) (2009: special supporting interest rate is $4 \%$ ) } \\
\hline
\end{tabular}

Table 8: Estimating beta results for Viet Nam Listed Medical equipment Companies (as of Dec 2012) (Source: Vie Nam stock exchange data).

\begin{tabular}{|c|l|l|l|l|l|}
\hline Order No. & Company stock code & Equity beta & $\begin{array}{c}\text { Asset beta (assume } \\
\text { debt beta }=0 \text { ) }\end{array}$ & Note & Financial leverage \\
\hline
\end{tabular}

How to cite this article: Dinh T N H. The Risk Level of Viet Nam Listed Medical and Human Resource Company Groups After the Global Crisis $2009-2011$. Significances Bioeng Biosci. 1(1). SBE.000503. 2017. DOI: 10.31031/SBB.2017.01.000503 in the medical industries is low while that of HR industry is little higher [21-23].

\section{Empirical Result}

In medical equipment industry, asset beta mean reach the lowest value $(0,029)$ and asset beta var reaches minimum $(0,001)$ compared to the rest 2 cases. In medicine industry, asset beta mean reach the highest value $(0,406)$ whereas asset beta var reaches medium value $(0,14)$, compared to the rest 2 cases. And finally, in human resource industry, equity beta mean reaches medium value $(0,469)$ while asset beta var reaches the highest value $(0,221)$, compared to the rest 2 cases (Table 7-9). 


\begin{tabular}{|c|c|c|c|c|c|}
\hline 1 & DNM & 0,168 & 0,056 & APC as comparable & $66,6 \%$ \\
\hline 2 & JVC & 0,025 & 0,003 & DNM as comparable & $88,5 \%$ \\
\hline & & & & Average & $77,55 \%$ \\
\hline
\end{tabular}

Table 9: Estimating beta results for Viet Nam Listed Human resource Companies (as of Dec 2012) (source: Viet Nam stock exchange data).

\begin{tabular}{|c|c|c|c|c|c|}
\hline Order No. & Company stock code & Equity beta & $\begin{array}{c}\text { Asset beta (assume } \\
\text { debt beta }=0 \text { ) }\end{array}$ & Note & Financial leverage \\
\hline 1 & CMS & $-0,063$ & $-0,016$ & VCM as comparable & 0,743937 \\
\hline 2 & ILC & 0,635 & 0,226 & SDA as comparable & 0,645102 \\
\hline 3 & SDA & 1,502 & 0,958 & & 0,361982 \\
\hline 4 & VCM & $-0,199$ & $-0,058$ & & 0,710539 \\
\hline & & & & Average & 0,61539 \\
\hline
\end{tabular}

\section{Risk Analysis}

Generally speaking, during the financial crisis 2007-2011 (Figure 1) esp. the period 2007-2009, the medical equipment and medicine industries can survive well and maintain the development and profits, although these firms have to face other kinds of risks: inventory management, materials or water or electric prices increasing. These risks can affect the operating cash flow of these companies. Next, the HR industry can experience the movement of labor work force across various industries under the crisis impacts. In short, the more debt the firm uses the more risk it takes. Beside, the increasing interest on loans might drive the earning per share (EPS) lower. On the other hand, in the case of increasing leverage, the company will expect to get more returns. The financial leverage becomes worthwhile if the cost of additional financial leverage is lower than the additional earnings before taxes and interests (EBIT). FL has become a positive factor linking finance and growth in many companies. Beside, leverage choice could also become a determinant of firms' capital structure and financial risk.

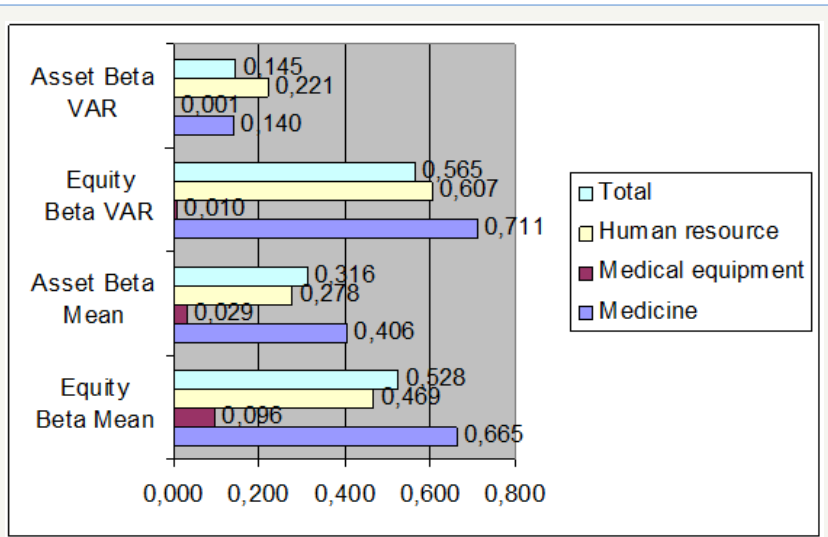

Figure 1: Statistical results of three (3) groups of 14 listed VN medical and human resource firms during/after the crisis period 2007-2011.

(Source: Viet Nam stock exchange 2012).

\section{Discussion}

Looking at Figure 2 it is noted that comparing to beta results of electronic and electrical industry in the period 2007-2011, asset beta mean of medicine industry group during 2009-2011 is higher
$(0,406)$. And the risk dispersion in medicine industry during 20092011 (shown by asset beta var of 0,14 ) is also higher than that in software and hardware industries (Figure 3,4).

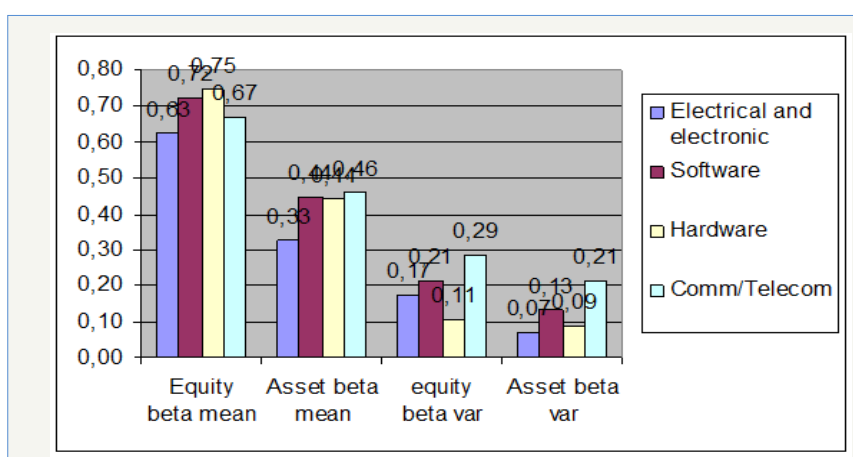

Figure 2: Statistical results of four (4) groups of 64 listed VN computer and electrical firms during/after the crisis period 2007-2011.

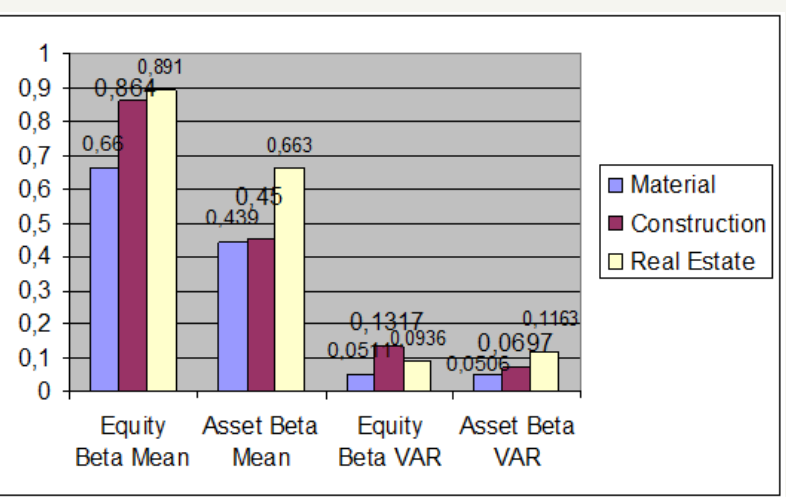

Figure 3: Statistical results of three (3) groups of 103 listed construction firms during crisis period.

\section{Conclusion and Policy Suggestion}

In general, the government has to consider the impacts on the mobility of capital in the markets when it changes the macro policies. Besides, it continues to increase the effectiveness of building the legal system and regulation supporting the plan of developing medical and human resource market. The Ministry of Finance continues to increase the effectiveness of fiscal policies and tax policies which are needed to combine with other macro 
policies at the same time. The State Bank of Viet Nam continues to increase the effectiveness of capital providing channels for medical and human resource companies as we could note that in this study when using leverage, the risk level decreases $(<0,7)$ much as well as the asset beta var $(<0,3)$. Furthermore, the entire efforts among many different government bodies need to be coordinated. Finally, this paper suggests implications for further research and policy suggestion for the Viet Nam government and relevant organizations, economists and investors from current market conditions.

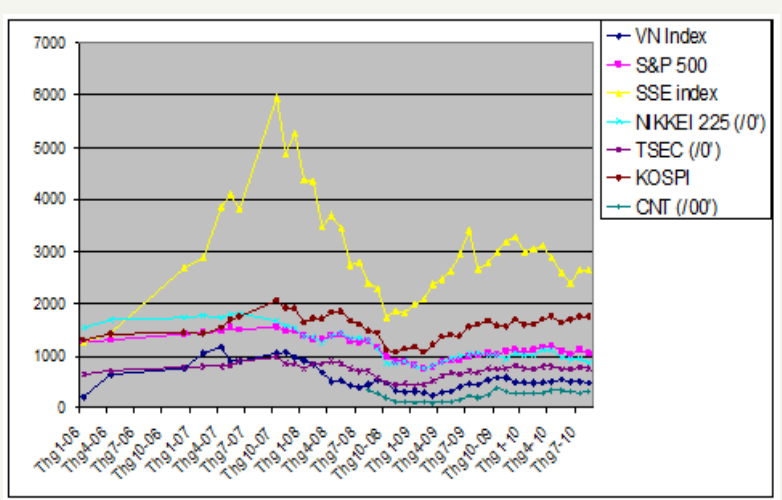

Figure 4:VNI Index and other stock market index during crisis 2006-2010.

(Source: Viet Nam stock exchange 2012).

\section{References}

1. Eugene FF, French KR (2004) The Capital Asset Pricing Model: Theory and Evidence. Journal of Economic Perspectives 18(3): 25-46.

2. Pereiro LE (2010) The Beta Dilemma in Emerging Markets. Journal of Applied Corporate Finance 22(4): 110-122.

3. Umar (2011) Profits, Financial Leverage and Corporate Governance.

4. Chen RR, Chidambaran NK, Imerman MB, Sopranzetti BJ (2013) Liquidity, Leverage, and Lehman: A Structural Analysis of Financial Institutions in Crisis. Fordham School of Business Research Paper No. 2279686 .

5. Alcock J, Baum A, Colley N, Steiner E (2013) The Role of Financial Leverage in the Performance of Private Equity Real Estate Funds. Journal of Portfolio Management 39(5): 99-110.
6. Gunaratha V (2013) The Degree of Financial Leverage as a Determinant of Financial Risk: An Empirical Study of Colombo Stock Exchange in Sri Lanka. $2^{\text {nd }}$ International Conference on Management and EconomicsFaculty of Management and Finance, University of Ruhuna, Sri Lanka.

7. Franck B, Usha RM (2011) Financial Flexibility and the Impact of the Global Financial Crisis: Evidence from France. International Journal of Managerial Finance 7(2): 179-216.

8. Bijlsma MJ, Boone J, Zwart G (2012) Competition for Traders and Risk. TILEC Discussion Paper No. 3.

9. Baker HK, Singleton CJ, Veit TE (2011) Survey Research in Corporate Finance: Bridging The Gap Between Theory and Practice, Oxford University Press, India.

10. David B, Juan P, Pim VV (2012) The Volatility Effects in Emerging Markets.

11. Dimitrov V, Jain PC (2006) The Value Relevance of Changes in Financial Leverage.

12. Huy DTN (2013) Estimating Beta of Viet Nam Listed Public Utilities, Natural Gas and Oil Company Groups During and After The Financial Crisis 2007-2011. Economic and Business Review 15(1): 57-71.

13. Maia MV (2010) Cash-Flow Risks, Financial Leverage and the Cross Section of Equity Returns. SSRN Working Paper.

14. Mamun MAA (2013) Performance Evaluation of Prime Bank Limited in Terms of Capital Adequacy. Global Journal of Management and Business Research 13(9): 26-29.

15. Ovat $O 0$ (2013) Liquidity Constraints and Entrepreneurial Financing in Nigeria: The Fate of Fresh Graduate Entrepreneurs. Global Journal of Management and Business Research 13(9): 49-57.

16. Ang A, Chen J (2007) CAPM Over the Long Run: 1926-2001. Journal of Empirical Finance 14(1): 1-40.

17. (2010) ADB and Viet Nam Fact Sheet

18. http://www.mofa.gov.vn/vi/

19. http://www.hsx.vn/hsx/

20. www.tuoitre.com.vn

21. www.saigontimes.com.vn

22. www.mof.gov.vn

23. www.vneconomy.com.vn 